\title{
Recruitment of Village Apparatus in the Regions and Implementation
}

\author{
Suwari Akhmaddhian \\ Faculty of Law, University of Kuningan
}

email: suwari_akhmad@uniku.ac.id

\begin{abstract}
The purpose of this article is to find out how the rules for the appointment of a village apparatus in the area and to know the implementation of the appointment at every level of village apparatus in the area. The research method used is empirical normative data collection through literature study, observation and interviews. The research location is Kuningan Regency, West Java. The results of the study are that the regulation on the selection of village apparatus is regulated in Law Number 6 of 2014 concerning Villages while the implementation of the local government issued Regional Regulation of Kuningan Regency Number 13 of 2015 concerning Village Apparatus and Kuningan Regent Regulation Number 73 of 2015 concerning Procedure for Appointment, Dismissal and Transfer of Position of Village Apparatus. Factors that predominantly influence the implementation of the appointment of the village apparatus are the lack of community knowledge related to regulations related to the selection of village apparatus so that there is a need for educational activities to the community related to regulations at the regional level.
\end{abstract}

Keywords : Recruitment; Position; Village Apparatus.

\section{INTRODUCTION}

Regional Reform and Autonomy is new hope for the government and the village community to build their villages according to the needs, potential, and aspirations of the city. For most village government apparatus, autonomy is a new opportunity that can open creative space for the village apparatus in managing the village, for example, all things to be done by the village government must go through the district approval route, for now, this does not apply anymore 1 . In the administration of government affairs by the regional government, it is carried out with the principle of local autonomy, which means that the rights, authorities, and obligations of the autonomous region to regulate and manage their own government affairs and the interests of the local community, in accordance with statutory regulations. This implies that central government affairs which are the authority of the central government cannot possibly be carried out as well as possible by the central government in favor of public services and public welfare in all regions.

Geographical conditions, political systems, legal, social and cultural, very diverse and patterned, on the other hand, the Unitary Republic of Indonesia, which includes areas

${ }^{1}$ Mangoto, Karlos. (2016). Fungsi Badan Permusyawaratan Desa (BPD) dalam Pengawasan penyelenggaraan Pemerintahan di Lesah Kecamatan Tagulandang Kabupaten Kepulauan Sitaro. Politico: Jurnal Ilmu Politik, Universitas Sam Ratulangi, 5(1), p. $1-2$. 
in the form of islands and the vast regions of the country. Therefore, matters concerning government affairs that can be carried out by the regions themselves, it is very appropriate to be given an autonomy policy so that each part will be more capable and independent to provide services and to improve the welfare of the people in the area. An autonomous region is a legal community unit that has territorial boundaries, which has the authority to regulate and manage government affairs and interests of the local community according to their initiatives, based on the aspirations of the people in the system of the Unitary State of the Republic of Indonesia, which has several elements including elements of territorial boundaries, aspects of government and perspective of society. In addition to these elements, there are also many principles implemented in the administration of governmental affairs between the principle of decentralization, the law of deconcentration, and the principle of co-administration². The development of regional autonomy, of course, some things become the leading indicators, namely the Equity and Improvement of Development in the Region, Improvement of Services for the Community, Optimization of Natural Resources, and Human Resources in the Regions. ${ }^{3}$

The Village Government gets influence from the environment in the form of regulations and policies, resources, and local technology so that it becomes the input for the implementation of the Village Government in the form of development and funding programs as happened in the Village located in Kuningan Regency. The process of providing government services at the village level is carried out by village government apparatus and local institutions, or with assistance from parties outside the village. The process is carried out according to Law No. 6 of $2014^{4}$ concerning Villages. Expected outcomes are clear boundaries of towns and areas, results of facilities and infrastructure, the fulfillment of primary or basic needs, conclusions of economic ventures, revolving funds, social assistance and grants for poor people, village government services, various social activities that increase community knowledge, attitudes and skills. The benefits that can be drawn from these results include an increase in the effectiveness of the village government to accelerate and improve access and quality of village government services to the community, accelerated village development, community empowerment, community institutional development, and security and order stability. Sustainable benefits produce the expected impacts in the form of improving the quality of life, life, and welfare of the community, and reducing poverty as well as achieving self-reliance, village income, and village competitiveness. ${ }^{5}$

\footnotetext{
${ }^{2}$ Sunarno, Siswanto. (2009). Hukum Pemerintahan Daerah di Indonesia. Jakarta: Sinar Grafika, p. 6.

${ }^{3}$ Moonti, Roy Marthen. (2019). Regional Autonomy in Realizing Good Governance. Substantive Justice International Journal of Law, Universitas Muslim Indonesia, 2(1), pp. 43 - 53. doi: http://dx.doi.org/10.33096/ substantivejustice.v2i1.31

${ }^{4}$ Law of the Republic of Indonesia Number 6 of 2014 concerning Villages. State Gazette of the Republic of Indonesia, Number 7 of 2014. Supplement to the State Gazette of the Republic of Indonesia, Number 5495.

IIrawan, Nata. (2017). Tata Kelola Pemerintahan Desa Era Undang-Undang Desa. Jakarta: Yayasan Obor Indonesia, p. 13
} 
As a legal community unit that has an original arrangement based on exclusive rights of origin. The rationale for village governance is diversity, participation, genuine autonomy, democratization, and community empowerment. ${ }^{6}$ In Article 48 of Government Regulation No. 43 of $2014^{7}$ concerning Regulation of Implementing Law Number 6 of 2014 concerning Villages, in carrying out the duties, authorities, rights, the village head is obliged to submit a report on the implementation of the Village Government at the end of the budget year to the Regent/Mayor, submit a report on the implementation of the Village Government at the end of the term position to Regent/Mayor, submit written statement of information to the Village Consultative Body at the end of each budget year.

Furthermore, as referred to in Article 51 of Government Regulation No. 43 of 2014 that the village head submits a report on the implementation of the Village Government, and Article 48 letter (c) that at the end of the fiscal year to the Village Consultative Body in writing no later than three months after the end of the fiscal year. The report on the implementation of the Village administration, as referred to in paragraph 1, shall at least contain the implementation of the Village regulations. From the description, it is clear that the Village Consultative Body has a strategic role in participating in overseeing the use of the Village funds so as not to be misused. In addition to being with the Village Consultative Body, according to the law that the village head is assisted by the village apparatus. The village apparatus is appointed by the village head after consultation with the subdistrict head on behalf of the Regent/Mayor, in carrying out their duties and authorities the Village apparatus is responsible to the village head. The village apparatus is appointed from villagers who meet the requirements because the village administration's tasks are so heavy, the village apparatus must have sufficient capabilities to be able to support the village head in running the government and development.

The village government is obliged to carry out government tasks in accordance with its authority. In Article 18 of Law No. 6 of 2014, it is stated that the Village's jurisdiction includes the body in the administration of village governance, implementation of village development, village community development, and empowerment of village communities, based on community initiatives, fundamental rights, and village customs. To carry out these tasks, it is necessary to have an adequate organizational structure and Village apparatus to be able to hold the government well. Thus the current organizational structure of the village government needs to be developed following the need to carry out the mandate of the Village law. The village apparatus as referred to in Article 48 shall be appointed from the villagers who fulfill the requirements:

${ }^{6}$ Widjaja, H. A. W. (2003). Pemerintahan Desa Berdasarkan Undang-Undang Nomor 22 Tahun 1999 tentang Pemerintahan Daerah: Suatu Telaah Administrasi Negara. Jakarta: PT. Raja Grafindo Persada, p. 3.

${ }^{7}$ Government Regulation of the Republic of Indonesia Number 43 of 2014 concerning Regulation of Implementing Law Number 6 of 2014 concerning Villages. State Gazette of the Republic of Indonesia, Number 123 of 2014. Supplement to the State Gazette of the Republic of Indonesia, Number 5539. 
a. The lowest educated public high school or equivalent;

b. Aged 20 (twenty) years to 42 (forty-two) years;

c. Registered as a resident of the Village and residing in the Village at least 1 (one) year before registration; and

d. Other requirements specified in Regency/City Regulations.

Further provisions regarding the Village apparatus, as referred to in Article 48, Article 49, and Article 50 paragraph (1), are regulated in District/City Regional Government Regulations based on Government Regulations. Still, in reality, many Village apparatuses are not following existing regulations or are applicable and assumed at the research location of this article, this raises many problems from the sharing of the community asking for transparency from the village regarding the appointment of the village apparatus. Whether in this way will have a good effect on the town or even create new problems for the city and the community, this will only consume energy that is actually more needed by the village community to escape from the snares of poverty and the economic crisis of the village. Based on the background that has been described above, in general, what will be discussed in this article are as follows: What is the arrangement of the principle of openness in the appointment of the Village apparatus in Kuningan Regency? And How is the implementation of the policy of transparency in the election of the right Village apparatus in Kuningan Regency?

\section{METHOD}

The method of approach used is empirical normative and sees the law as a symptom of society as a social institution or behavior that shapes and approaches from the standpoint of the rules of implementing the applicable regulations in the community. Data obtained through library research, observation, and interviews. The legal materials used are the 1945 Constitution $^{8}$, Law No. 6 of 2014, Law No. 9 of $2015^{9}$ concerning Second Amendment to Law No. 23 of $2014^{10}$ concerning Regional Government, Regional Regulation of Kuningan Regency No. 13 of $2015^{11}$ concerning Village Apparatus, and Kuningan Regent Regulation No. 73 of $2015^{12}$ concerning Procedure for Appointment, Dismissal and Transfer of Position of Village Apparatus.

\footnotetext{
${ }^{8}$ The 1945 Constitution of the Republic of Indonesia.

'Law of the Republic of Indonesia Number 9 of 2015 concerning Second Amendment to Law Number 23 of 2014 concerning Regional Government. State Gazette of the Republic of Indonesia, Number 58 of 2015. Supplement to the State Gazette of the Republic of Indonesia, Number 5679.

${ }^{10}$ Law of the Republic of Indonesia Number 23 of 2014 concerning Regional Government. State Gazette of the Republic of Indonesia, Number 244 of 2014. Supplement to the State Gazette of the Republic of Indonesia, Number 5587.

${ }^{11}$ Regional Regulation of Kuningan Regency Number 13 of 2015 concerning Village Apparatus. Regiona Gazette of Kuningan Regency, Number 13 Series E of 2014.

${ }^{12}$ Kuningan Regent Regulation Number 73 of 2015 concerning Procedure for Appointment, Dismissal and Transfer of Position of Village Apparatus. Regional Gazette of Kuningan Regency, Number 74 of 2015.
} 


\section{ANALYSIS AND DISCUSSION}

\section{A. Arrangement of Appointment of the Village Apparatus in Kuningan Regency Based on Law Number 6 of 2014 concerning Villages}

According to Article 1 Paragraph (1) of Law No. 6 of 2014, that a Village is a Village and a Customary Village or referred to by another name, from now on incorporated to as a Village is a legal community unit that has an area boundary authorized to regulate and administer government affairs, the interests of the local community based on community initiatives, original rights, and/or traditional rights that are recognized and respected in the system of government of the Unitary Republic of Indonesia.

Article 1 Paragraphs (2) and (3) of Law No. 6 of 2014, explained that the Village Government is the administration of government affairs and the interests of the local community in the system of government of the Unitary Republic of Indonesia. Village Government is the head of the Village or referred to by another name assisted by the Village apparatus as an element of Village administration.

The appointment of the Village apparatus is regulated in Article $48-53$ of Law No. 6 of 2014. According to Article 48 of Law No. 6 of 2014 that the Village apparatus consists of: the Village Secretariat, regional executors, and technical implementers. According to Article 49 of Law No. 6 of 2014, the number of village apparatus is adjusted to the needs, characteristics of the village, and the financial capacity of the town. The village office is located as an element of the village head's assistant who in carrying out his duties is responsible for the village head.

Article 50 of Law No. 6 of 2014, explains that the Village apparatus is appointed from villagers who fulfill the requirements, namely: 1) The lowest level of education is a public high school or equivalent; 2) aged 20 years to 42 years; 3 ) registered as a resident of the Village and residing in the Village at least one year before registration, and 4) other conditions specified in the Regulations of the Regency/City. Further provisions regarding the Village apparatus are regulated in District/City Regional Regulations based on Government Regulations.

The ban on village apparatus according to Article 51 of Law No. 6 of 2014, includes: 1) detrimental to the public interest; 2) make decisions that benefit themselves, family members, other parties and/or particular groups; 3) misuse of authority, duties, rights, and/or obligations; 4) discriminatory actions against individual citizens and/or groups of society; 5) take action to unsettle a group of Village people; 6) collusion, corruption and nepotism, receiving money, goods, and/or services from other parties that can influence the decisions or actions that will be taken; 7) becomes a manager of political parties; 8) become a member and/or administrator of a prohibited organization; 9) concurrently a position as chairman and/or member of the Village 
Consultative Body, members of the People's Representative Council of the Republic of Indonesia, the Regional Representative Council of the Republic of Indonesia, the Provincial Regional Representative Council or the Regency/City Regional People's Representative Council, and other positions determined in the legislation invitation; 10) participate in and/or be involved in general election campaigns and/or regional head elections; 11) breaking oaths/promises of village apparatus; and 12) leave assignments for 60 consecutive working days without apparent reason and cannot be justified. According to Article 52 of Law No. 6 of 2014, Village apparatus who violate the prohibition are subjected to administrative sanctions in the form of verbal warnings and/or written warnings. If administrative penalties are not carried out, temporary termination is taken and can be continued with dismissal.

Article 53 of Law No. 6 of 2014, describes the dismissal of the Village apparatus where the Village apparatus ceases due to death, own request, or termination. Village apparatus who were dismissed because age has reached 60 years; permanent absence; no longer qualifies as a village apparatus, or violate the ban as a Village apparatus. The termination of the Village apparatus is determined by the Village Head after consultation with the District Head on behalf of the Regent/Mayor. Further provisions are regulated in a Government Regulation.

The procedure for the appointment of the Village apparatus is also regulated in Minister of Home Affairs Regulation No. 83 of $2015^{13}$ concerning Appointment and Dismissal of the Village Apparatus which explains that the Village apparatus is appointed by the Village head from the Village residents who have fulfilled the general and special requirements as follows:

1. General requirements include several things, namely:

a. The lowest educated public high school or equivalent.

b. Aged 20 (twenty) years to 42 (forty-two) years.

c. Registered as a resident of the Village and residing in the Village at least 1 (one) year before registration.

d. Fulfilling the administrative requirements, consisting of:

1) Resident Identity Card or Certificate of Residence for at least 1 (one) year before registration from the Local Neighborhood Association or Community Unit.

2) Statement of loyalty to God Almighty made by the person concerned on stamped paper.

3) An explanation of upholding and practicing Pancasila, the 1945 Constitution, maintaining and maintaining the integrity of the Unitary State

${ }^{13}$ Minister of Home Affairs Regulation of the Republic of Indonesia Number 83 of 2015 concerning Appointment and Dismissal of the Village Apparatus. State Gazette of the Republic of Indonesia, Number 5 of 2016. 
of the Republic of Indonesia and Unity in Diversity, which was made by the person concerned on sealed or sufficiently stamped paper.

4) School diplomas from the primary level up to the last degree, which is legalized by the authorized official or a statement from the authorized official.

5) Birth Certificate or Birth Identification Certificate.

6) Certificate of good health from the health center or licensed health apparatus.

7) Application to become a Village apparatus made by the person concerned on a seal or sufficiently stamped paper.

2. Special requirements are special requirements that pay attention to the rights of origin and socio-cultural values of the local community and other conditions. Special needs stipulated in regional regulations.

The mechanism for appointing village apparatus is regulated by Article 4 of the Minister of Home Affairs Regulation No. 83 of 2015 as follows:

1. The Village Head can form a team consisting of a chairperson, a secretary, and at least one member.

2. The Village Head conducts the selection and selection of the Village apparatus candidates conducted by the team.

3. The collection and selection of prospective village apparatuses shall be carried out no later than 2 (two) months after the position of the village apparatus is vacant or dismissed.

4. The results of the selection and screening of prospective village apparatuses at least 2 (two) candidates are consulted by the village head to the sub-district head.

5. The Camat provides written recommendations to prospective village apparatus no later than 7 (seven) working days.

6. The guidance given by the camat is approval or rejection based on the specified requirements.

7. In case the camat provides permission, the village head issues a village head's decree on the appointment of village apparatus.

8. In the case of a camat's recommendation containing a rejection, the village head conducts a selection and re-screening of the village apparatus candidates.

9. Further arrangements regarding the tasks and functions of the team, as referred to in paragraph (1) letter a are regulated in the Regulation of the Village Head.

The appointment of the Village apparatus in Kuningan Regency is further regulated by Regional Regulation of Kuningan Regency No. 13 of 2015 and Regional Regulation of Kuningan Regency No. 5 of $2017^{14}$ concerning Amendment to Regional

${ }^{14}$ Regional Regulation of Kuningan Regency Number 5 of 2017 concerning Amendment to Regional Regulation No. 13 of 2015 concerning Village Apparatus. Regional Gazette of Kuningan Regency, Number 5 of 2017. 
Regulation No. 13 of 2015 concerning Village Apparatus that the appointment of Village apparatus is the authority of the head Villages with a mechanism, namely: the Village Head does the selection and selection or selection of candidates for the Village apparatus; The Village Head consulted with the sub-district head about the appointment of the Village apparatus; The Camat gave written recommendations that contained the prospective village apparatus that had been asked by the village head, and the written advice of the camat is used as a basis by the village head in appointing village apparatus by the decision of the village head.

\section{B. Implementation of Appointment of the Village Apparatus in Kuningan Regency Based on Law Number 6 of 2014 concerning Villages}

The $4^{\text {th }}$ paragraph of the 1945 Constitution states that to form an Indonesian government that protects all of Indonesia and all of Indonesia's blood and to promote public welfare, develop the life of the nation, and participate in carrying out public order to educate life nation and to participate in carrying out world order based on independence, regional regulations and servants and social justice, Indonesian independence was compiled in the form of the 1945 Constitution. Based on Article 18 paragraph (5) states that the regional government operates autonomy to the broadest possible extent, except for government affairs, which by law are determined as central government affairs.

As the implementation of the mandate of the Article above, Law No. 9 of 2015 , in the law stating that regional autonomy is the right, authority and obligation of autonomous regions to regulate and manage their government affairs and the interests of the local community in the system of the Unitary Republic of Indonesia, ${ }^{15}$ then need to look at several principles including:

a. The principle of decentralization implies the transfer of several government affairs from the central or higher-level regional government to the lower level provincial government so that it becomes the household's affairs of the region. ${ }^{16}$ Law No. 9 of 2015 , whereby the central government to local governments based on the principle of autonomy.

b. The principle of deconcentration implies a delegation of authority from the central government or regional heads or heads of higher-level vertical agencies to their apparatus in the regions. ${ }^{17}$ As determined in Law No. 9 of 2015, that deconcentration is the delegation of part of government affairs which is the authority of the central government to the governor as the representative of the central government, to vertical instances in certain regions, and the governor of the general government.

${ }^{15}$ Kansil, C. S. T., \& Kansil, Cristine S. T. (2007). Pemerintahan Daerah di Indonesian: Hukum Administrasi Daerah. Jakarta: Sinar Grafika, p. 3.

${ }^{16} / \mathrm{bid}$., p. 8.

${ }^{17}$ lbid. 
c. Co-administration tasks, in addition to the local government which has the right to regulate and manage household affairs, can also be co-administered which is a task to carry out the affairs of the central government or the local government which has the right to regulate and manage the household level of its superior. In the assistance task, the relevant local government has the authority to regulate and administer it is limited solely to the administration. In Article 1 No. (9) of Law No. 32 of $2004^{18}$, it is stated that the task of assistance is the assignment of the provincial government to the regions and villages from the provincial government to the Regency/City and Village and from the Regency/City Government to Village to carry out specific tasks. ${ }^{19}$

The Village Consultative Body is a partner of the Village Head in carrying out his duties and authority. Membership of the BPD is the representative and the inhabitants of the Village based on regional representation, which is filled in a democratic manner. The number of BPD members is determined by the number of odd, at least 5 (five) people at the most 9 (nine) people, taking into account the region, women, residents, and Village Finance capabilities. While the inauguration is determined by the decision of the Regent/ Mayor. Village Head, which is six years and after that, can be re-elected for 3 (three) times in a row or not in a row. While the duties and functions of the BPD are: Discuss and agree on the Village Regulation Draft with the Village Head. Accommodate and channel the aspirations of the village community and supervise the performance of the village head ${ }^{20}$.

Based on the results of research conducted on Monday, August 12, 2019, at the Cileuleuy Village Office, Cigugur Sub-district, Kuningan Regency with Mr. Nendi Suhendi as Head of the Cileuleuy Village, said that concerning the application of the principle of openness in the appointment of a suitable Village apparatus, the Cileuleuy Village always provides information to the community as a whole. Clear about the void of the village apparatus by making a sheet and giving announcements in mosques or places of worship and public areas. Furthermore, in the process of appointing village apparatus, the Village Head refers to Article $48-53$ of Law No. 6 of 2014. Mr. Nendi Suhendi further explained that the implementation of Village apparatus recruitment in the village of Cileuleuy had been carried out by applicable regulations where the Village apparatus recruitment consisted of several stages, namely the formation of the committee and facilitation team, the registration stage, the verification stage, the scene of providing recommendations, endorsement, and inauguration. ${ }^{21}$

${ }^{18}$ Law of the Republic of Indonesia Number 32 of 2004 concerning Regional Government. State Gazette of the Republic of Indonesia, Number 125 of 2004. Supplement to the State Gazette of the Republic of Indonesia, Number 4437.

19Joniarto. (1982). Pemerintahan Lokal: Asas Negara Kesatuan dengan Otonomi yang Seluas-Luasnya dan Perkembangan serta Pokok-Pokok Pemerintahan Lokal. Yogyakarta: Yayasan Badan Penerbit Gadjah Mada, p. 14.

${ }^{20}$ Roby, Anselmus. (2015). Fungsi Badan Permusyawaratan Desa dalam Pengawasan Penyelenggaraan Pemerintahan di Desa Pak Laheng Kecamatan Toho Kabupaten Mempawah. Governance: Jurnal Mahasiswa Program Studi Ilmu Pemerintahan, Universitas Tanjungpura, 4(3), pp. 1 - 13.

${ }^{21}$ Interview with Mr. Nendi Suhendi, Head of Cileuleuy Village. Monday, August 12, 2019, at 09.30 WIB. 
Based on the results of research conducted on Monday, August 12, 2019, in Cileuleuy Village, Cigugur Sub-district, Kuningan Regency, some residents showed that not all residents received adequate information about the vacancy of the village apparatus. This happens because not all public places or public facilities are available to announce the job of the village apparatus. Besides, the existence of traditions or culture of family relations in the village government hierocracy also influences the selection of village apparatus in the village of Cileuleuy. The results of the author's observations occurred in the past few years. ${ }^{22}$ Thus, the application of the principle of openness in the appointment of the Village apparatus in the Cileuleuy Village has not been fully implemented to the fullest.

Based on the results of research that has been done by researchers through observations in Cileuleuy Village, Cisantana Village, and Puncak Village, Cigugur Subdistrict, Kuningan Regency, the data of village apparatus appointment for the past few years is presented in the following table:

\begin{tabular}{|c|c|c|c|}
\hline $\begin{array}{c}\text { No. Name of the Village } \\
\text { Apparatus }\end{array}$ & Position & Education Level & Period \\
\hline \multicolumn{4}{|c|}{ Cileuleuy Village } \\
\hline 1. Mina Yuniar, S.Pd. & Head of Financial Affairs & Undergraduate & $2017-2018$ \\
\hline 2. Tri Ria Feridiana, S.Pd. & Treasurer & Undergraduate & $2017-2018$ \\
\hline 3. Andri Budiman & $\begin{array}{l}\text { Head of Government } \\
\text { Section }\end{array}$ & Undergraduate & $2017-2018$ \\
\hline 4. Rudi Harono & $\begin{array}{l}\text { Head of Development } \\
\text { Economics Section }\end{array}$ & Senior High School & $2017-2018$ \\
\hline 5. Ivan Irvana E.P. & $\begin{array}{l}\text { Head of Sub-Village } \\
\text { Manis }\end{array}$ & Senior High School & $2017-2018$ \\
\hline \multicolumn{4}{|c|}{ Cisantana Village } \\
\hline 1. Aji Rianto, S.T. & Secretary & Undergraduate & 2017 \\
\hline 2. Wandi A.M. & $\begin{array}{l}\text { Head of Sub-Village } \\
\text { Cisantana }\end{array}$ & Senior High School & 2017 \\
\hline 3. Tono Kartono & $\begin{array}{l}\text { Head of Sub-Village } \\
\text { Sukamanah }\end{array}$ & Senior High School & 2017 \\
\hline 4. Uun Nuramah, A.Md & Treasurer & Diploma III & 2017 \\
\hline 5. Iyon Ramdani, S.Pd.I & Treasurer & Undergraduate & 2018 \\
\hline \multicolumn{4}{|c|}{$\begin{array}{l}\text { Puncak Village } \\
\end{array}$} \\
\hline 1. Noli Liander & Head of Sub-Village Ciuni 1 & Senior High School & 2016 \\
\hline 2. $\quad$ Bangkit Peri Kurnia & Head of Financial Affairs & Senior High School & 2016 \\
\hline 3. Asep Supriatna & Treasurer & Senior High School & 2016 \\
\hline 4. Asep Saefulloh & $\begin{array}{l}\text { Head of Sub-Village } \\
\text { Pakembaran }\end{array}$ & Senior High School & 2017 \\
\hline 5. Irwanto & $\begin{array}{l}\text { Head of the People's } \\
\text { Welfare Section }\end{array}$ & Senior High School & 2017 \\
\hline
\end{tabular}

Table 1. Appointment of Village Apparatus in Cigugur Sub-district, Kuningan

\section{Regency ${ }^{23}$}

\footnotetext{
${ }^{22}$ Interviews with Some of the People of Cileuleuy Village. Monday, August 12, 2019, at 12.30 WIB.

${ }^{23}$ Data Source: Cigugur Sub-district, 2019.
} 
Legal certainty is a question that can only be answered normatively, not sociology. ${ }^{24}$ Law as a norm system whose statements emphasize the supposed ideal or das sollen aspects, by conveying some rules about what must be done. Norms are born as a product and deliberative human action. Laws that contain general rules are a guideline for individuals behaving in society, both in relationships with fellow individuals and in relation to society. The rule becomes a limit for the community in burdening or taking action against individuals, then the existence of the rule and the implementation of the rule raises legal certainty. ${ }^{25}$

The legal theory used in analyzing this paper is the theory of legal certainty, namely regarding a particular (condition), provisions, or provisions. The law must be absolutely specific and fair, certainly as a guideline of conduct and fair because the code of conduct must support an order that is considered reasonable. Only because it is appropriate and carried out with certainty the law can carry out its functions. Normative legal certainty is when specific regulations are made and promulgated because they regulate clearly and logically, clearly, in the sense of not raising doubts and logical. Clearly, in the sense that it becomes a norm system with other norms so that they do not clash or cause norm conflicts. Legal certainty refers to the implementation of transparent, permanent, consistent and consistent laws whose application cannot be influenced by subjective circumstances. Confidence and justice are not just moral demands but factually characterize the law. A law that is uncertain and does not want to be fair is not only bad. ${ }^{26}$

Related to the above theory, the application of the principle of openness in the appointment of a proper Village apparatus in Cileuleuy Village, Cigugur Subdistrict, Kuningan Regency, has been regulated in Article $48-53$ of Law No. 6 of 2014. The law explains that the village apparatus is appointed from villagers who fulfill the requirements, namely: a) the lowest educated public high school or equivalent; b) aged 20 years to 42 years; c) registered as a resident of the Village and residing in the Village at least one year before registration; and d) other conditions specified in the Regulations of Regency/City. Further provisions regarding the Village apparatus are regulated in District/City Regional Regulations based on Government Regulations.

Soerjono Soekanto uses a benchmark of effectiveness in law enforcement on five things: legal factors, law enforcement factors, supporting facilities or elements, community factors, and cultural factors. ${ }^{27}$ The five factors can be explained further as follows:

${ }^{24}$ Rato, Dominikus. (2010). Filsafat Hukum: Mencari Memahami dan Memahami Hukum. Yogyakarta: LaksBang PRESSindo, p. 59.

${ }^{25}$ Marzuki, Peter Mahmud. (2008). Pengantar Ilmu Hukum. Jakarta: Kencana Prenada Media Group, p.158.

${ }^{26}$ Kansil, C. S. T., \& Kansil, Cristine S. T. (2007). Loc. Cit.

27 Akhmaddhian, Suwari. (2016). Penegakan Hukum Lingkungan dan Pengaruhnya terhadap Pertumbuhan Ekonomi di Indonesia (Studi Kebakaran Hutan Tahun 2015). Unifikasi: Jurnal Ilmu Hukum, Universitas Kuningan, 3(1), pp. 1 - 35. doi: https://doi.org/10.25134/unifikasi.v3i1.404. 
1) Legal factors. The law functions to achieve justice, certainty and expediency. In practice in carrying out law in the field there are times when there is a conflict between legal certainty and justice. Legal certainty is concrete tangible, whereas justice is abstract so that when a judge decides on a case by applying the law alone, there are times when the value of justice is not achieved. So when seeing a problem about the law at least justice is a top priority. Because law is not merely seen from the perspective of written law.

2) Law enforcement factors. In the functioning of the law, the mentality or personality of law enforcement apparatus an important role, if the rules are good, but the quality of apparatus is not good, there is a problem. During this time there is a strong tendency among the public to interpret the law as an officer or law enforcer, meaning that the law is identified with the real behavior of the officer or law enforcer. Unfortunately in carrying out their authority, problems often arise because attitudes or treatments that are seen as exceeding the authority or other actions that are considered to fade the image and authority of law enforcement. This is due to the low quality of the law enforcement apparatus.

3) Factors supporting facilities or facilities. Factors supporting facilities or facilities include software and hardware. Law enforcers cannot work properly if they are not equipped with vehicles and proportional communication devices. Therefore, facilities or facilities have a very important role in law enforcement. Without these facilities or facilities, it is not possible for law enforcement to harmonize their roles with their actual roles.

4) Community factors. Law enforcement comes from the community and aims to achieve peace in the community. Every citizen or group more or less has legal awareness. The problem that arises is the level of legal compliance, namely high, moderate, or poor legal compliance. The degree of community legal compliance with the law, is one indicator of the functioning of the law in question.

5) Cultural factors. Culture basically includes the values that underlie applicable law, which values are abstract conceptions of what is considered good (so obeyed) and what is considered bad (so avoided). Therefore, Indonesian culture is the basis or underlying customary law. Besides that also applies written law, which is formed by certain groups in society who have the power and authority for it. The law must be able to reflect the values that form the basis of customary law, so that the law can be actively applied.

Factors that hinder or influence the process of recruiting a good Village apparatus in Cileuleuy Village, Cigugur Sub-district, Kuningan Regency based on Law No. 6 of 2014 and Soerjono Soekanto's theory of effectiveness benchmarks in law enforcement can be explained as the results of the following research: ${ }^{28}$

${ }^{28}$ Interview with Mr. Nendi Suhendi, Head of Cileuleuy Village. Monday, August 12, 2019, at 09.30 WIB. 
1) Legal factors, namely the existence of laws and regulations governing the process of recruiting village apparatus in the form of Law No. 6 of 2014, Minister of Home Affairs Regulation No. 83 of 2015, and Regional Regulation of Kuningan Regency No. 11 of $2015^{29}$ concerning Organizational Structure and Administration of Village Governments. These laws and regulations relate to the process of recruiting village apparatus in Cileuleuy Village, Cigugur Sub-district, Kuningan Regency.

2) Law enforcement factors, namely the Village Head as the legal implementer in the process of recruiting Village apparatuses and the Village Consultative Body as the supervisor of the Village apparatus recruitment process. In connection with this research, law enforcement is carried out by the Village Head and the Village Consultative Body (BPD) of Cileuleuy Village, Cigugur Sub-district, Kuningan Regency. But in the implementation there are obstacles where the Village Head is more likely to use a family or kinship system in the selection of Village apparatus. In addition, BPD as the village government supervisor has not been able to carry out its functions optimally, especially in overseeing the performance of the village head in appointing village apparatus.

3) Factors of supporting facilities or facilities, namely the presence of computers, vehicles, and communication devices that support the recruitment process of the Village apparatus based on Law No. 6 of 2014. However, in practice, the village government has not been able to maximize the facilities/facilities that are owned to better support the recruitment process of the Village apparatus in Cileuleuy Village, Cigugur Sub-district, Kuningan Regency as social media and internet have not been used to socialize Village apparatus recruitment.

4) Community factors, namely the contribution or participation of the community in the process of recruiting village apparatus based on Law No. 6 of 2014. In connection with this study, the community in Cileuleuy Village, Cigugur Subdistrict, Kuningan Regency did not participate and contributed in the process of recruiting village apparatus. The attitude of the community still uses the traditional mindset, customs, habits of the people. The lack of community participation in this matter is related to the orderly implementation of the village government. Many people do not care or can be said to be indifferent to the activities carried out by the village government. In addition, the majority of community education in the basic education category (elementary and junior high school graduates) also influences community participation and contribution in the process of recruiting village apparatus in Cileuluy Village.

${ }^{29}$ Regional Regulation of Kuningan Regency Number 11 of 2015 concerning Organizational Structure and Administration of Village Governments. Regional Gazette of Kuningan Regency, Number 11 Series D of 2015. 
5) Cultural factors, namely the culture of the local community that influence the process of recruiting village apparatus. In connection with this research, cultural factors that influence the recruitment process of the village apparatus in Cileuleuy Village, Cigugur Sub-district, Kuningan Regency are feeling of insecurity, as many villagers do not want to become village apparatus because they feel they are less capable. Insecurity can make a person unsure of his abilities so it is difficult to explore and bring up his potential. This makes it difficult for people to develop because they themselves do not want to develop in accordance with their potential.

\section{CONCLUSION}

Based on the discussion, it can be drawn some conclusions that are also the core of this research, namely: the regulation and implementation in the appointment of the Village apparatus in Kuningan Regency based on Law No. 6 of 2014, Regional Regulation of Kuningan Regency No. 13 of 2015, and Kuningan Regent Regulation No. 73 of 2015. The factors that hinder or influence the process of recruiting a good Village apparatus in Cileuleuy Village, Cigugur Sub-district, Kuningan Regency include several things, namely: Village heads are more likely to use a family or kinship system in the selection of Village apparatuses; BPD has not been able to carry out its functions to the maximum; the use of social media or the internet is not yet used to socialize the recruitment of village apparatus; community attitudes still use the traditional mindset, customs, community habits and education, the majority in the basic education category; and cultural factors where the community tends to feel insecure about being a village apparatus because they feel less able.

\section{SUGGESTION}

Based on the conclusions that have been described, the researcher submits several suggestions for related parties as follows: The community must actively participate and cooperate appropriately by participating in activities carried out by the village government, including in the process of appointing village apparatus. The village government needs to conduct broader and more comprehensive dissemination related to the operation of selecting village apparatus through print and electronic media so that the community can obtain sufficient information about the implementation of village apparatus recruitment Besides, it is necessary to avoid a familial/kinship approach in the process of appointing village apparatus. The Regional Government must strive to conduct training and outreach activities to the community related to their roles and participation to increase their confidence and quality in the administration of fair and prosperous village governance. 


\section{ACKNOWLEDGEMENT}

The author, thanks to the University of Kuningan and Regional Government of Kuningan Regency and all parties for all the support that has been given so that the implementation of research activities.

\section{REFERENCE}

Akhmaddhian, Suwari. (2016). Penegakan Hukum Lingkungan dan Pengaruhnya terhadap Pertumbuhan Ekonomi di Indonesia (Studi Kebakaran Hutan Tahun 2015). Unifikasi: Jurnal IImu Hukum, Universitas Kuningan, 3(1), 1 - 35. doi: https://doi. org/10.25134/unifikasi.v3i1.404

Government Regulation of the Republic of Indonesia Number 43 of 2014 concerning Regulation of Implementing Law Number 6 of 2014 concerning Villages. State Gazette of the Republic of Indonesia, Number 123 of 2014. Supplement to the State Gazette of the Republic of Indonesia, Number 5539.

Irawan, Nata. (2017). Tata Kelola Pemerintahan Desa Era Undang-Undang Desa. Jakarta: Yayasan Obor Indonesia.

Joniarto. (1982). Pemerintahan Lokal: Asas Negara Kesatuan dengan Otonomi yang SeluasLuasnya dan Perkembangan serta Pokok-Pokok Pemerintahan Lokal. Yogyakarta: Yayasan Badan Penerbit Gadjah Mada.

Kansil, C. S. T., \& Kansil, Cristine S. T. (2007). Pemerintahan Daerah di Indonesian: Hukum Administrasi Daerah. Jakarta: Sinar Grafika.

Kuningan Regent Regulation Number 73 of 2015 concerning Procedure for Appointment, Dismissal and Transfer of Position of Village Apparatus. Regional Gazette of Kuningan Regency, Number 74 of 2015.

Law of the Republic of Indonesia Number 32 of 2004 concerning Regional Government. State Gazette of the Republic of Indonesia, Number 125 of 2004. Supplement to the State Gazette of the Republic of Indonesia, Number 4437.

Law of the Republic of Indonesia Number 6 of 2014 concerning Villages. State Gazette of the Republic of Indonesia, Number 7 of 2014. Supplement to the State Gazette of the Republic of Indonesia, Number 5495.

Law of the Republic of Indonesia Number 23 of 2014 concerning Regional Government. State Gazette of the Republic of Indonesia, Number 244 of 2014. Supplement to the State Gazette of the Republic of Indonesia, Number 5587. 
Law of the Republic of Indonesia Number 9 of 2015 concerning Second Amendment to Law Number 23 of 2014 concerning Regional Government. State Gazette of the Republic of Indonesia, Number 58 of 2015. Supplement to the State Gazette of the Republic of Indonesia, Number 5679.

Mangoto, Karlos. (2016). Fungsi Badan Permusyawaratan Desa (BPD) dalam Pengawasan penyelenggaraan Pemerintahan di Lesah Kecamatan Tagulandang Kabupaten Kepulauan Sitaro. Politico: Jurnal Ilmu Politik, Universitas Sam Ratulangi, 5(1), 1-11.

Marzuki, Peter Mahmud. (2008). Pengantar IImu Hukum. Jakarta: Kencana Prenada Media Group.

Minister of Home Affairs Regulation of the Republic of Indonesia Number 83 of 2015 concerning Appointment and Dismissal of the Village Apparatus. State Gazette of the Republic of Indonesia, Number 5 of 2016.

Moonti, Roy Marthen. (2019). Regional Autonomy in Realizing Good Governance. Substantive Justice International Journal of Law, Universitas Muslim Indonesia, 2(1), 43 - 53. doi: http://dx.doi.org/10.33096/substantivejustice.v2i1.31

Rato, Dominikus. (2010). Filsafat Hukum: Mencari Memahami dan Memahami Hukum. Yogyakarta: LaksBang PRESSindo.

Regional Regulation of Kuningan Regency Number 11 of 2015 concerning Organizational Structure and Administration of Village Governments. Regional Gazette of Kuningan Regency, Number 11 Series D of 2015.

Regional Regulation of Kuningan Regency Number 13 of 2015 concerning Village Apparatus. Regional Gazette of Kuningan Regency, Number 13 Series E of 2014.

Regional Regulation of Kuningan Regency Number 5 of 2017 concerning Amendment to Regional Regulation No. 13 of 2015 concerning Village Apparatus. Regional Gazette of Kuningan Regency, Number 5 of 2017.

Roby, Anselmus. (2015). Fungsi Badan Permusyawaratan Desa dalam Pengawasan Penyelenggaraan Pemerintahan di Desa Pak Laheng Kecamatan Toho Kabupaten Mempawah. Governance: Jurnal Mahasiswa Program Studi IImu Pemerintahan, Universitas Tanjungpura, 4(3), 1 - 13.

Sunarno, Siswanto. (2009). Hukum Pemerintahan Daerah di Indonesia. Jakarta: Sinar Grafika.

The 1945 Constitution of the Republic of Indonesia.

Widjaja, H. A. W. (2003). Pemerintahan Desa Berdasarkan Undang-Undang Nomor 22 Tahun 1999 tentang Pemerintahan Daerah: Suatu Telaah Administrasi Negara. Jakarta: PT. Raja Grafindo Persada. 